\title{
The Effects of Feedback on Focal Epileptic Discharges in Man

\author{
A Preliminary Report
}

\author{
A. R. M. UPTON AND D. LONGMIRE
}

SUMMARY: The history of the control of epileptic disturbances by conditioning techniques is reviewed. The preliminary results of a three year trial of feedback techniques in 13 epileptic patients are presented.

Thirteen epileptic patients (age 2.5

$\rightarrow 39$ mean, 15.1 years) with lateralized focal discharges in the EEG were given repeated trials of feedback, the focal discharges being used to trigger auditory and somatosensory stimuli. Dosages and serum levels of medication were unchanged throughout the experimental period. The number of epileptic spikes per 15 seconds was assessed by automatic trend analysis during 20 to 30 minute control, biofeedback and post-feedback epochs. Ongoing EEG activity was quantified by 8 channel frequency analysis over 10 second epochs. The patients made efforts to increase and decrease the number of spike discharges with and without feedback and the results of both triggered and random auditory, somatosensory, photic and combined stimulation were compared at various intervals

RÉSUME: L'histoire du contrôle des désordres épileptiques par des techniques de conditionnement est redite. Les résultats préliminaires de 3 ans d'essai des techniques de rétroaction chez 13 patients épileptiques sont présentés.

Une réduction marquée dans le nombre de décharges focales était notée chez huit patients (61.5\%) durant et immédiatement après les sessions de rétroaction.

Les sessions de rétroaction intermittentes ne furent pas associées avec une

From the Department of Medicine (Neurology), McMaster University Medical Centre, Hamilton, Ontario, Canada.

Reprint request to Dr. A. R. M. Upton, McMaster University Medical Centre, 1200 Main St. W., Hamilton, Ontario, Canada. over a period of up to three years. A marked reduction in the number of focal discharges was noted in eight (61.5\%) patients during and immediately following the sessions,

Intermittent biofeedback sessions were not associated with a serial reduction in the number of focal EEG discharges. There was a reduction in the number of clinical epileptic disturbances in six patients (46\%) and possible reasons for this improvement are discussed.

One patient suffered an increase in focal temporal lobe discharges during triggered and random auditory stimulation whereas there was a marked reduction in the number of discharges during minimal electrical stimulation of the contralateral arm. The need for careful assessment of each patient to determine appropriate feedback stimulation is stressed.

One aim of this research has been to assess the feasibility of using miniature units for continuous feedback of focal discharges in epileptic patients.

réduction sériée dans le nombre de décharges focales à l'EEG, mais il y eut une réduction dans le nombre de manifestations épileptiques cliniques chez 6 patients (46\%).

La nécessité d' une évaluation soignée de chaque patient pour déterminer la stimulation appropriée en rétroaction est mise en lumière. Un des buts de cette recherche était d'évaluer la possibilité d'utiliser des unités miniaturisées pour une rétroaction continuelle des décharges focales chez les patients épileptiques.

\section{INTRODUCTION}

Biofeedback experiments began 74 years ago (Bair, 1901). Conditioning of EEG rhythms (Durup, 1935; Jasper and Shagass, 1941; Shagass, 1942; Mulholland and Runnals, 1962; Nowlis and Kamiya, 1970; Sacks et al, 1972) and the use of such techniques to modify epileptic activity (Sterman et al, 1969) are more recent developments. Attempts to inhibit or arrest seizures by physiological methods were made in the time of Galen (A.S. 131-201) and Aurelianus (1755) and in recent years there have been papers on the defence mechanisms used by patients to arrest or control focal seizures (Bures, 1953; Efron, 1956, 1957; Symonds, 1961; Paulson, 1963). A number of authors have discussed methods of inhibiting or arresting seizures by various forms of conditioning (Maier, and Glaser, 1947; Efron, 1957; Naquet, 1961; Booker et al, 1964; Forster et al, 1965; Forster et al, 1967; Forster et al, 1969; Korein et al, 1971). Over the last three years we have applied biofeedback techniques to 13 epilep. tic patients using auditory and somatosensory (electric shock) stimuli triggered by lateralised, focal discharges in the electroencephalogram.

\section{History of Conditioning}

Procedures Applied to Epilepsy

Galen and Aurelianus were aware that certain stimuli might precipitate seizures and both also mentioned strangulation of a limb as an effective defence mechanism against the spread of a focal seizure (Aurelianus, 1755). In recent years there has been further interest in the defence mechanisms used by patients 
to arrest the advancement of focal fits, often as a result of their own fortuitous experiences. Such findings are usually discussed in terms of "reflex arrest" of the seizure and this has been thought to be an important measure in about $6 \%$ of epileptic (Bures, 1956). Some authors have claimed that up to a third of epileptic patients may be able to inhibit some of their seizures after the aura has begun (Paulson, 1963) by using mental and physical activity (Symonds, 1961).

Efron $(1956,1957)$ described a woman with uncinate fits who could inhibit her attacks with a powerful olfactory stimulus. She experienced a complete cure of her epilepsy, after many years of frequent seizures, when a conditioned reflex was formed by associating an unconditioned olfactory stimulus with a visual stimulus. Stevens (1961) demonstrated suppression of focal EEG activity in epileptic patients during repetitive peripheral stimulation, but there was an augmentation of spiking at the termination of stimulation. She did not discuss the effect of this stimulation on the frequency of subsequent seizures and no attempt was made to condition the patient. She observed the immediate effects of flickering light, rhythmic click, tone, tactile and olfactory stimulation on 66 epileptic patients with focal-cortical or centencephalic epilepsy. Maier and Glaser (1947) observed that a decrease in acoustic epileptic seizures might follow the presentation of accoustic stimuli which did not provoke a seizure, and they attributed the improvement to adaptation, a view supported by Chocholova (1962).

Naquet (1961) found that photosensitive seizures could be modified by giving repeated stroboscopic stimulation in rapid succession, but he found that conditioning only appeared in discharges existing at rest and he felt it would be difficult to apply these techniques clinically. However, Forster and his colleagues (1964) successfully used conditioning (extinction) techniques to reduce the number of stroboscopically induced seizures in patients. They used monocular stimulation as a neutral stimulus and repeated extinction trials inhibited cortical hypersyncnrony and clinical seizures due to binocular stimulation. They noted a marked specificity of extinction of seizure activity for a particular frequency but the patient remained moderately sensitive at other frequencies. There was no indication that the extinction was permanent, but the low thresholds at the start of the tests were never reached after the extinction trials.

Forster (1969) used similar conditioning techniques to treat a patient with voice induced epilepsy and the same principles have been applied to startle (Booker et al, 1965), musicogenic (Forster et al, 1965) and audiogenic (Forster et al, 1967) epilepsy. In the later experiment, a triggering sound stimulus was presented as a continuous tone to patients with audiogenic epilepsy and it was claimed that some could be kept seizure-free.

It would seem likely that various unconscious associations may occur in epileptic patients and these may act to increase or decrease the chance of a seizure while the form of a seizure may be influenced by environmental factors at the time of the attack. Forster and Liske (1963) described a number of such cases, one example being a young woman who developed a deviation of the head and eyes during automatic seizures, the side of the deviation depending on the side from which she was approached during the attacks.

The results of experiments in animals are also relevant. As early as 1850 Brown-Sequard showed that epilepsy in guinea pigs might be provoked by chronic irritation of receptors in the trigeminal zone by dermal parasites and the epilepsy ceased with their elimination.

Burés $(1953,1956)$ and Petran (1953) demonstrated that painful stimuli or stimulation of the stomach or bladder had the greatest influence in reducing the susceptibility to audiogenic seizures in rats. A conditioned alimentary reflex in rats to an acoustic epileptogenic stimulus resulted in a persistent loss of the epileptogenic effect of the stimulus, an alimentary reaction replacing the audiogenic seizure (Chocholova, 1962).

\section{Aggravation of Seizures}

Some patients may be able to provoke a seizure by imitating the convulsion (Gorbacevich, 1955) or by hyperventilation. Fabisch (1965) reported the case of a boy who could induce epileptic fits by hyperventilation. His attacks temporarily ceased after some were followed by vomiting, an unpleasant stimulus.

In some cases seizures may be due to unconscious sensory or motor triggering mechanisms which the patient has learned to operate (Liddell, 1965). For example, Goldie and Green (1959) described a patient whose seizures were provoked by sensory impulses during movement of his face. Later the seizures could be precipitated when the patient moved his hand in a manner similar to that when rubbing his face. Another early example of such a problem involved a patient with attacks precipitated by movement of the lower limbs and subsequently the sight of an athlete running or reading about a sprint record was enough to cause a clinical seizure (Pitha, 1938). Such associations seem to develop in dogs (Kreindler, 1955) and conditioned emotional responses may reduce the seizure threshold in dogs (Martinek and Horak, 1970) and Rhesus monkeys with aluminum gel lesions (Ward et al, 1948; Kopeloff et al, 1948, 1954; and Lockard et al, 1972).

Some experiments have been conducted to produce conditioned epilepsy in man (Gastaut et al, 1956) and it is possible to produce sensitivity to a previously neutral stimulus using Pavlovian conditioning techniques (Booker et al, 1965).

Any discussion of aggravating factors in epilepsy must mention general factors such as excitement, emotional strain and fatigue which may be important contributory and sometimes precipitating events in the occurrence of seizures (Small et al, 1964; Weinberg, 1945; Livingstone, 1956; Bennett, 1963; Bennett et al, 1964, 1964; and Gastaut and Tassinari, 1966). 
Some Disadvantages of

Conventional Treatment of Epilepsy

As a prelude to the discussion of feedback techniques as applied to the control of epilepsy, it may be helpful to review some of the disadvantages of other methods of treatment.

\section{Drug Therapy}

Conventional treatment of epileptics includes the initial use of medications and most patients can be kept free of seizures if they take the medications correctly with adequate monitoring of serum levels (Kutt and Penry, 1974). However, it is known that anticonvulsant medications may have many unwanted effects. For example, diphenylhydantoin may cause folic and deficiency (Reynolds, 1967), soft tissue changes (Merritt, 1947), lymphomatous disorders (Rosenfeld et al, 1961) growth inhibition (Kraft et al, 1974), osteomalacia (Knise, 1968) and teratogenic effects (Meadow, 1968, 1970). Severe and fatal exfoliative dermatitis has been reported after phenobarbitone therapy (Welton, 1950; Snedden and Leishman, 1952). Newer anticonvulsants may cause a wide range of blood dyscrasias (Best, 1963). Phenacemide may be toxic to the liver (Craddock, 1955) whereas trimethadione or paramethadione may cause renal impairment including the nephrotic syndrome (Finkel and Israels, 1959). Since most of these toxic effects are rare, the clinical benefit seems to outweigh the risks, but the long term effects of anticonvulsants may be more difficult to assess, particularly in children with developing nervous systems. Acceptance of such effects may not be so reasonable when it is known that epileptics without medication may remain seizure-free for long periods (Kuligowski et al, 1972). In a study of 987 epileptics in Iceland, Gudmundsson (1966) found that $32 \%$ of untreated epileptics were seizure-free for longer periods than treated epileptics and only $42 \%$ of epileptics had been treated regularly at the time of the examination. Similar results were obtained in Poland by Zeilinski (1974). A quarter of known epileptics and two-thirds of patients with a history of a single fit, found in a survey of 15,000 persons, were not on treatment. Zeilinski pointed out that long-lasting remissions could occur in epileptics even though treatment was discontinued early or was never given. It is clear from these results that "mild" epileptics may be under-represented in studies of known epileptics and this fact must be taken into account when the results of any form of treatment are assessed.

\section{Surgical Treatment}

Another way to relieve epilepsy would be to remove the nervous tissue which triggers the seizures, but surgical management of epilepsy must be distinguished from surgical treatment of lesions which may produce epilepsy such as tumors or subdural hematomas. Surgery may be used to relieve uncontrollable focal epilepsy if the patient is deteriorating despite other treatments (Penfield and Erickson, 1941). If careful assessment of the patients is achieved (Penfield and Steelman, $1947), 56 \%$ of the patients may be seizure-free after surgery. However, surgical management of epileptics has been vigorously criticized by Meyers (1954) and Bates (1962) even though surgery in temporal lobe epilepsy has been strongly advocated (Falconer and Taylor, 1968; Falconer, 1953). Ammons horn sclerosis (Falconer and Corsellis, 1964) was thought to be common in temporal lobe epileptics and was thought to arise from pyrexial fits and anoxia in infancy. However, a recent study of 666 cases of temporal lobe epilepsy failed to reveal an increased incidence of pyrexial fits in established temporal epileptics (Currie et al, 1971). Even though surgery has been advocated for bilateral and independently discharging lesions of the temporal lobes (Falconer and Kennedy, 1961) the criticisms of destructive treatment are:

(a) The observation that discharging epileptic foci may develop in cell populations remote from the primary cortical focus (Wilder and Morell, 1967; Wada and Cornelius, 1960; Guerrero-Figueroa et al, 1964; Holubar, 1966; Hughes, 1966, 1967; Wil- der and Morell, 1967; Nie et al, 1973).

(b) The difficulty of correlating a discharging focus with an underlying lesion as the interictal focal discharges may be remote from the primary lesion (David et al, 1970).

(c) The removal of useful brain tissue.

Although the surgical treatment may lead to control or abolition of the fits in $70 \%$ of the cases (Currie et al, 1971), a less destructive and reversible treatment would still allow the use of surgery later if treatment failed. It is clear that surgical removal of tissue in primary motor and sensory areas may create more of a handicap than benefit and therefore patients with focal discharges in these areas must turn to some other form of treatment.

\section{CNS Stimulation}

Less destructive methods of controlling epileptic discharges have involved direct stimulation of the brains of animals and man. There may be active arresting mechanisms in epilepsy (Jung, 1949; Gastaut and Fischer-Williams, 1959; Fernandez-Guardiola et al, 1961; Kreindler, 1965) and various areas of the brain may play an inhibitory role. In addition to cortical mechanisms, subcortical structures in the diencephalon may produce inhibitory effects on seizure discharges (Green and Shimamoto, 1953). The caudate, (Gastaut and Fischer-Williams, 1959; Gastaut et al, 1958; Jung, 1949; La Grutta et al, 1971) reticular formation (LairyBounes et al, 1952; Arduini and Lairy-Bounes, 1952; FernandezGuardiola, et al, 1956, 1961, 1968) and cerebellum (Snider and Cooke, 1954, 1955; Dow et al, 1962; Dow, 1965; Reimer et al, 1967 and Mutani et al, 1969) are thought to have seizure-suppression effects even though strong stimulation of all these structures except the cerebellum may produce major epileptic seizures (Dow, 1965). Cooke and Snider (1955) demonstrated that cortical seizure discharges induced by electrical stimulation could be modified by cerebellar stimulation and Steriade (1960) showed inhibitory ef- 
TRIGGER CIRCUIT FOR AUTOMATIC TREND ANALYSIS OF SPIKE DISCHARGES

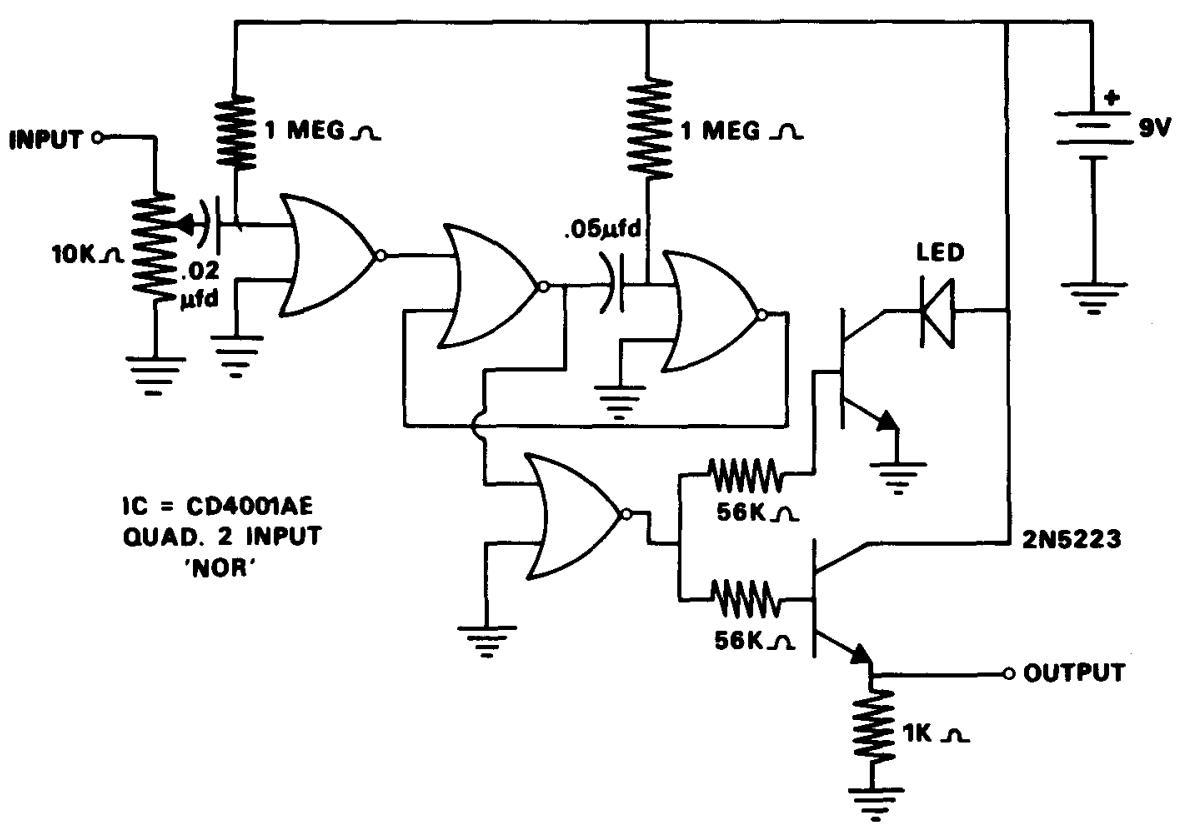

Figure 1-Trigger circuit for automatic trend analysis of spike discharges.

fects on penicillin-induced focal seizure activity. Dow $(1962,1965)$ demonstrated inhibitory effects of cerebellar stimulation on cobalt induced focal spikes in rats but not in cats. More recently, there have been attempts to apply such techniques to man using chronic cerebellar stimulation (Cooper et al, 1973).
The application of such techniques to the control of epilepsy in man may be limited by tissue damage near the site of stimulation $(\mathrm{Pu}-$ denz et al, 1975).

\section{Feedback techniques}

Since the conventional methods of treatment all have serious disadvan- tages, we examined the possibility of using feedback techniques as an alternative. We have already discussed some of the early experiments in the control of focal and reflex epilepsies by conditioning techniques, but four years ago we were unable to find any studies on the feedback control of focal EEG activity although conditioning of focal discharges has since been reported (Korein et al, 1971).

As early as 1901, Bair had conducted biofeedback experiments in which an unrelated movement could lead to an ear twitch. He rigged a small lever to an ear and recorded movements on a smoked drum. He noted that even feeble movement could be recognized and efforts were made to increase the sensation by improving the "sensorimotor" circuit.

Conditioning of EEG activity in man was first demonstrated by Adrian more than forty years ago (Adrian and Matthews, 1934; Durup, 1935) and soon afterwards Jasper and Shagass $(1941,1942)$ demonstrated conditioning of occipital alpha rhythms in man. Subsequently, many workers have used biofeedback techniques to teach patients how to control alpha activity (Mulholland and Runnals, 1962:

Figure 2-Biofeedback oscillator. a) Circuit Diagram. b) input/output frequency data.

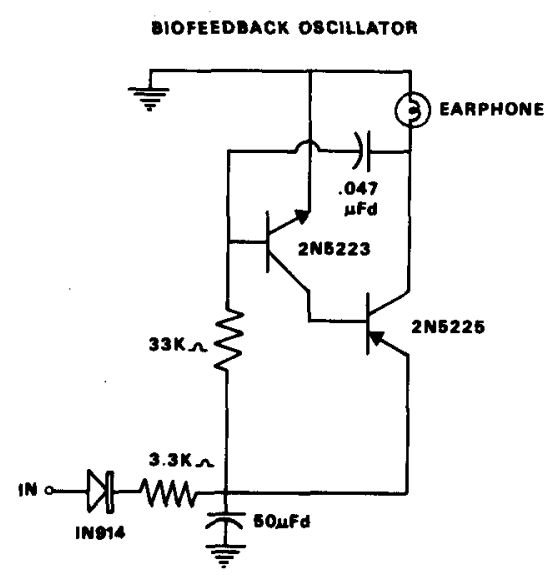

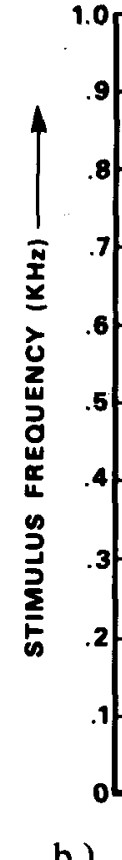

b.)
BIOFEEDBACK OSCILLATOR

INPUT VOLTAGE/OUTPUT FREQUENCY DATA

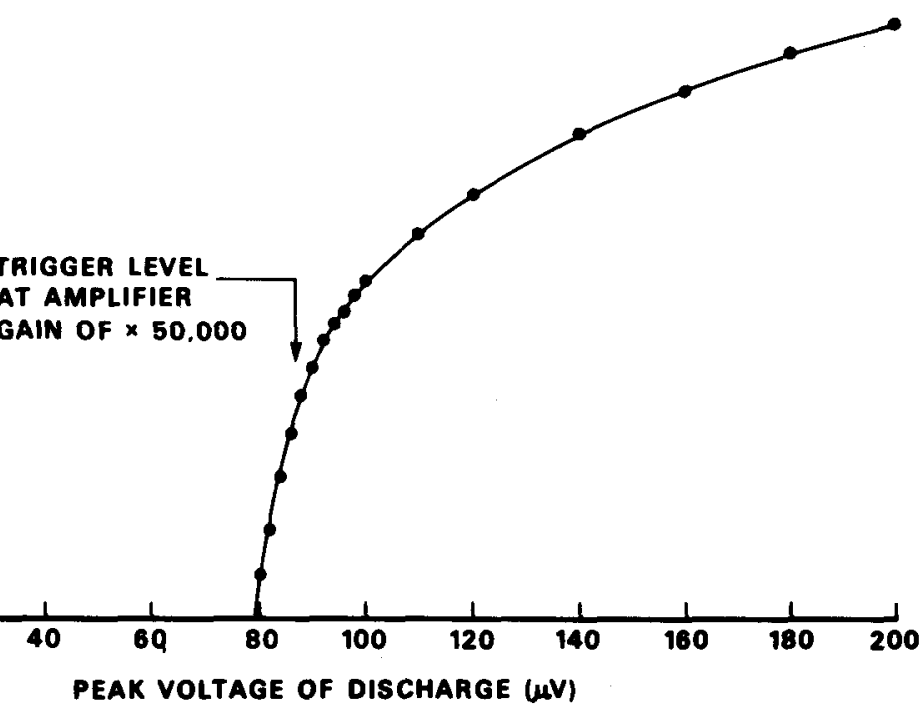


EEG BIOFEEDBACK AND AUTOMATIC TREND ANALYSIS SYSTEMS

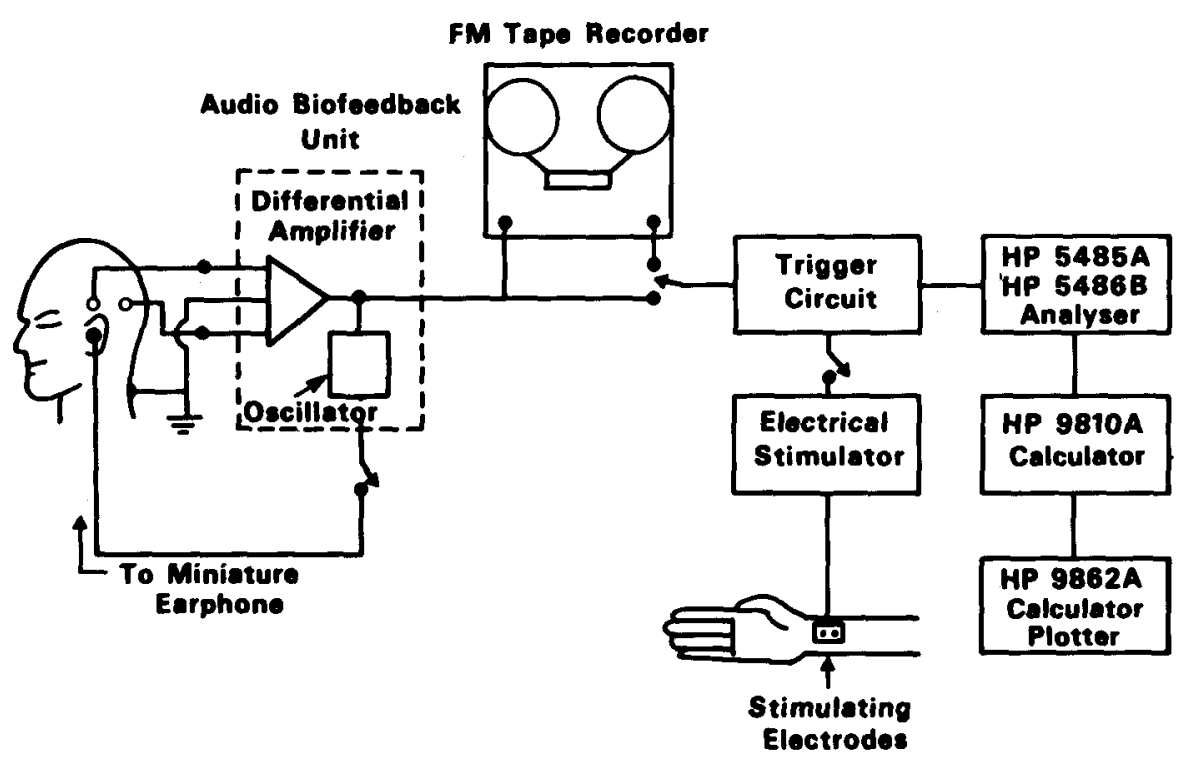

Figure 3-EEG biofeedback and trend analysis systems. Auditory and somatosensory (electric shock) stimulators are shown but other types of stimulus (e.g. Photic) can be triggered by the system. The trigger circuit is shown in Fig. 1. The oscillator is described in Fig. 2.

Figure 4-4A shows the topographic printout of the EEG Data Analysis System used as a supplement to visual analysis of the ongoing EEG. Polygons for each EEG channel represent the voltage/frequency outputs of four sixth order multiple bandpass filters, the outputs being half wave rectified and integrated over a 10 second epoch.

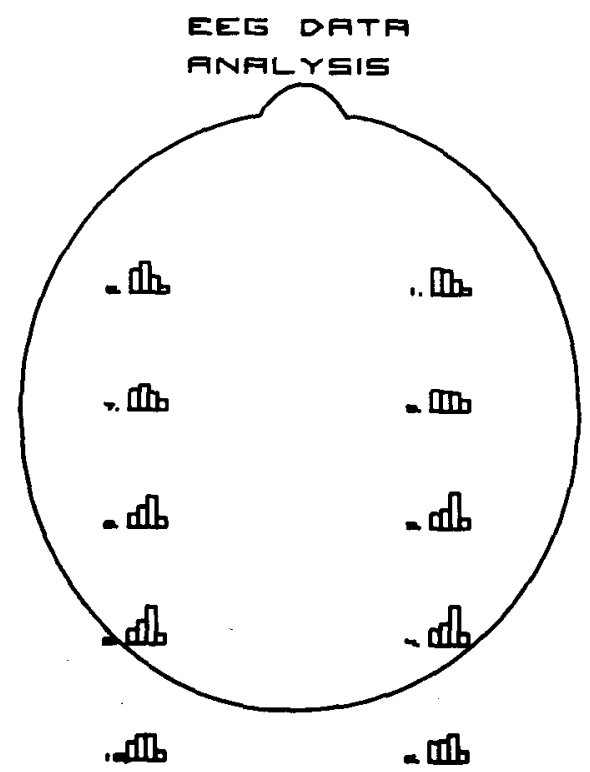

Mulholland, 1968; Nowlis and Kamiya, 1970; Sacks et al, 1972) and more recently the $12-17 \mathrm{~Hz}$ "sensorimotor" rhythm (SMR) in cats and man has been modified by biofeedback techniques. The SMR has been associated with relaxation (Roth et al, 1967) and absence of movement (Sterman and Wyrwicka, 1967) and these rhythms could be modified by conditioning involving food or positive brain stimulation reward (Wyrwicka and Sterman, 1968; Sterman et al, 1969, 1972). SMR training and suppression were studied and it was shown that overtraining for the production of the rhythm enhanced EEG spindle activity, reduced movements during sleep (Sterman et al, 1970) and reduced the total sleeptime (Lucas and Sterman, 1972, 1974). Of particular interest was the claim that SMR trained animals were resistant to seizures induced by intraperitoneal dosages of a convulsant drug, monomethylhydrazine (Sterman et al, 1969a; Sterman, 1972).

It was claimed that control of the SMR could lead to significant central neuronal organization (Sterman, 1973) which might result in a raised threshold for seizure discharges.

Figure $4 B$-The filters had centre frequencies of $2.5,5,10$ and $20 \mathrm{~Hz}$ with ultimate cutoffs of $18 \mathrm{DB}$ per octave. The lower polygons represent average outputs for each hemisphere. The system was designed and developed by T. Blogg, D. Teeple, and Glen Shine in our laboratories.

\section{FILTERS PER CHANNEL}

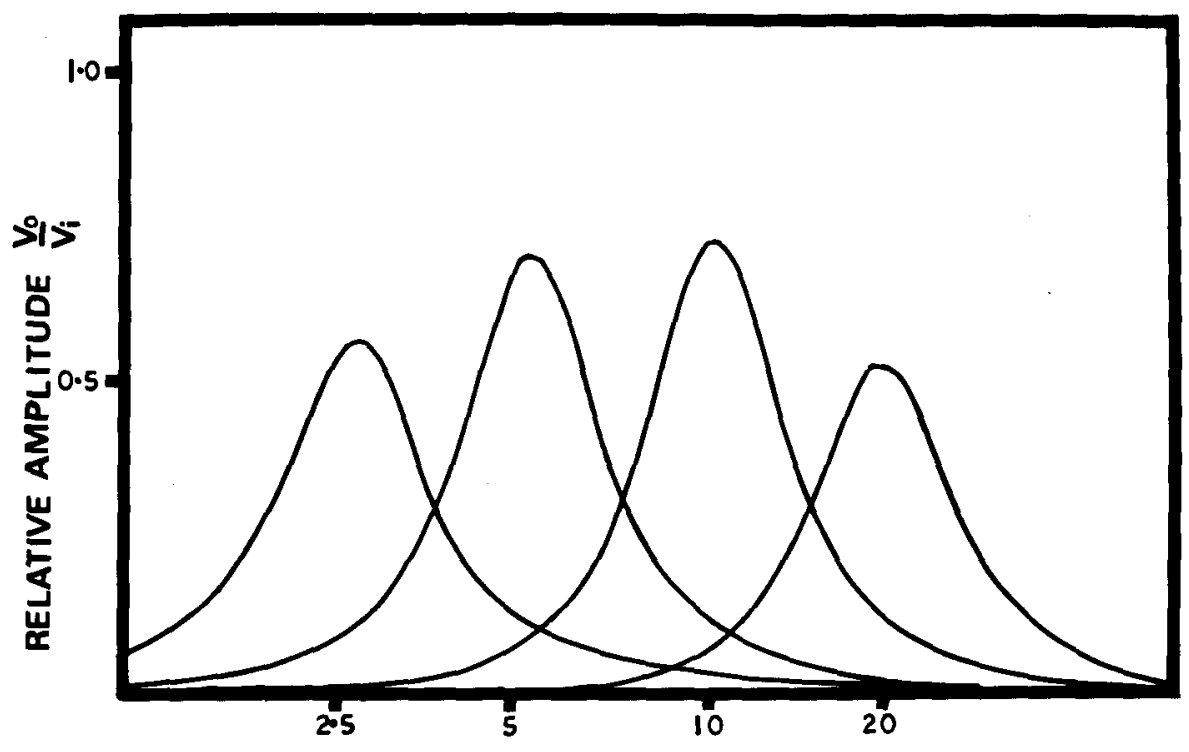

HERZ 
Or OFEEDBACK RESULTS TROM Feb. 2, 1972 to Feb. 2, 1975

\begin{tabular}{|c|c|c|c|c|c|c|c|c|c|c|c|c|c|}
\hline case 1 & Patient & Mge & Sex & $\begin{array}{l}\text { Iype of } \\
\text { Seizure }\end{array}$ & $\begin{array}{l}\text { EEG } \\
\text { ALn. }\end{array}$ & \begin{tabular}{|l|}
$\mathbf{s}$ \\
Sessions \\
\end{tabular} & & & & & Respons & & . \\
\hline & & & & & & & Audio & ؟.s. & Photic & $\begin{array}{c}\text { Audio } \\
+ \\
\text { Notor }\end{array}$ & $\begin{array}{l}\text { Random } \\
\text { Rudio }\end{array}$ & $\begin{array}{l}\text { Hotor } \\
\text { Only }\end{array}$ & Corment \\
\hline 1 & $7 . \mathrm{PCI}$ & 23 & $T$ & $\begin{array}{l}\text { Psvchomot. } \\
+ \text { Tonic }\end{array}$ & $\begin{array}{l}\text { Foca } \\
(F-T)\end{array}$ & 11 & + & + & HA & + &. & 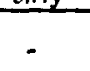 & Alcohol decrease \\
\hline 2 & R.P. & 30 & $"$ & frand "al & $\begin{array}{l}r o c a l \\
(F-T)\end{array}$ & 9 & + & $n$ & 0 & + & + & 0 & $\begin{array}{l}\text { Return to work } \\
\text { (accountant) }\end{array}$ \\
\hline 3 & C.s. & 7 & $F$ & $\begin{array}{l}\text { Trnor and } \\
\text { rrand } \mathrm{mal}\end{array}$ & Pocal & 4 & 0 & ++ & 0 & 0 & 0 & + & $\begin{array}{l}\text { Mmost continuous } \\
\text { atnormality }\end{array}$ \\
\hline$a$ & I!.F. & 11 & $\mathbf{F}$ & $\begin{array}{l}\text { Foca) } \\
(E . M .)\end{array}$ & $\begin{array}{l}\text { Tilat. } \\
\text { slow. }\end{array}$ & 1 & 0 & - & H.A. & + & - & H.A. & Poor trigger effect \\
\hline 5. & J.S. & 11 & $r$ & $\begin{array}{l}\text { Psycho- } \\
\text { motor }\end{array}$ & $\begin{array}{l}\text { bi- } \\
\text { Temp. } \\
\text { siow. } \\
\end{array}$ & 2 & $+-?$ & W.A. & H.A.] & H.A. & 0 & N.A. & $\begin{array}{l}\text { Uncooperative for } \\
\text { further testing }\end{array}$ \\
\hline 6. & $\therefore$. C. & 22 & $F$ & $\begin{array}{l}\text { Sensory } \\
\text { loss (aud. } \\
- \text { seizure } \\
\end{array}$ & $\begin{array}{l}\text { Focai } \\
\text { L. } \\
\text { iemp. }\end{array}$ & 4 & -- & + & 0 & - & - & N.A. & $\begin{array}{l}\text { Clinical seizure } \\
\text { with audio } \\
\text { stimulation }\end{array}$ \\
\hline$\%$ & s.l: & 14 & $F$ & $\begin{array}{l}\text { 6. Focal } \\
\text { onset }\end{array}$ & cent. & 2 & 0 & 0 & 0 & + & 0 & 0 & Poor school perf. \\
\hline$\varepsilon$. & U.J. & 25 & $M$ & $\begin{array}{l}\text { Reflex } \\
\text { Reading } \\
\text { Seizures }\end{array}$ & $\begin{array}{l}\text { Foca } \\
\text { (CZ) }\end{array}$ & 5 & - & $+?$ & 0 & ? & - & 0 & $\begin{array}{c}\text { Reading aggravated } \\
\text { discharges }\end{array}$ \\
\hline 9. & $0 . \because$ & 11 & M & $\begin{array}{l}\text { Rage out-- } \\
\text { bursts. No } \\
\text { Seizures }\end{array}$ & $\begin{array}{l}\text { R } \\
\text { Post. } \\
\text { Temp. }\end{array}$ & 1 & 0 & 0 & + & 0 & 0 & 0 & No clinical seiz. \\
\hline 10 & J.". & 14 & $F$ & $\begin{array}{l}\text { Raqe out- } \\
\text { bursts }+ \\
\text { psychomot. }\end{array}$ & $\begin{array}{l}\text { Temo. } \\
\text { Slow. }\end{array}$ & 2 & 0 & 0 & 0 & 0 & 0 & 0 & $\begin{array}{l}\text { Rehaviour and rage } \\
\text { outbursts }\end{array}$ \\
\hline 11. & F.R. & 4 & $\mathrm{~F}$ & atsence & $\begin{array}{l}\text { Focal } \\
\text { R.occ. } \\
(\mathrm{nZ})\end{array}$ & 2 & $t-?$ & - & -- & + & - & 0 & $\begin{array}{l}\text { To clinical } \\
\text { "alsence" episodes } \\
\text { for } 3 \text { months }\end{array}$ \\
\hline 12. & A.A. & $2 s$ & $\mathrm{~F}$ & $\begin{array}{l}\text { Tro- } \\
\text { clonic }\end{array}$ & $\begin{array}{l}\text { Focat } \\
(\mathrm{PA})\end{array}$ & 1 & $+?$ & 0 & II.A. & H.^. & H.A. & H.A. & $\begin{array}{l}\text { Oischarges } \\
\text { increased with } \\
\text { drowsiness }\end{array}$ \\
\hline 13. & L.H. & 13 & $F$ & $\begin{array}{l}\text { Tirand } \\
\mathrm{Mal}\end{array}$ & Worm. & 2 & 0 & 0 & H.A. & 0 & 0 & H.A. & $\begin{array}{l}\text { Onty two seizures } \\
\text { in } 6 \text { months. }\end{array}$ \\
\hline
\end{tabular}

+ improvement 0 Ho change - Deterioration H.A. not tested

Figure 5-Summary of the results of the first 13 patients seen between Feb. 21972 and Feb. 2, 1975.

+ improvement in number of focal EEG discharges.

0 No change in number of focal EEG discharges.

-Deterioration in number of focal EEG discharges.

N.A. Not tested.

One epileptic, studied over three months, showed a significant reduction in clinical symptoms as well as behavioural changes with SMR training (Sterman and Friar, 1972). Further studies (Sterman et al, 1974) involved four epileptic patients who received a minimum of three biofeedback training sessions per week for periods from 8 to 18 months. Four non-epileptic subjects were studied for periods from 2 to 3 months with similar training. These experiments were associated with a significant reduction in EEG and clinical epileptic manifestations as indicated by sequential power, spectral analysis, clinical EEG records and seizure logs; tonic/clonic and myoclonic seizures being most markedly reduced.
More recently Ward and his colleagues have used conditioning techniques to modify single neuronal activity in monkeys (Macaca mulatta) and they have applied similar methods to epileptic patients in the last year.

\section{Present Research Project}

The problem of control of epileptic seizures in man was approached by incorporating some of the features of the research, of Forster in reflex epilepsy, and Sterman in biofeedback training of the sensorimotor rhythm. It was thought to be logical to determine whether inhibitory mechanisms could be activated by biofeedback techniques in order to reduce focal EEG activity or arrest clinical epileptic fits at some stage of development. Further, it was thought that atraumatic techniques, using surface stimulating or recording electrodes, might have a wider application than methods using surgical procedures or indwelling electrodes. Focal EEG discharges were studied initially since it was possible to quantify the EEG and clinical effects during a number of experimental conditions.

It was decided to trigger an auditory or somatosensory stimulus from the focal EEG activity. The aims in this research were to see if the technique selected might be used:

$a$. To warn of impending epileptic activity by auditory or somatosensory stimuli. This could be used as indication for taking anticonvulsant medication, for ceasing the 


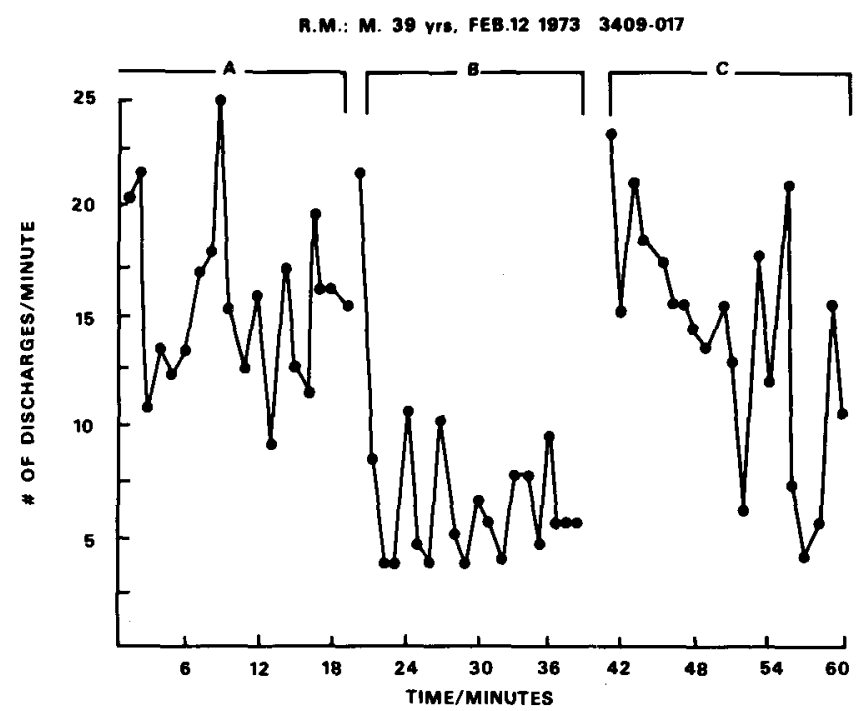

Figure 6-Trend analysis results on R.M.: M. 39 years. Feb. 12, 1973. (No. 3409-017). The number of spike discharges per minute are displayed for consecutive 20 minute epochs. A. Before feedback. B. During feedback of triggered auditory stimuli. C. After feedback. Note the reduction in the number of discharges during feedback.

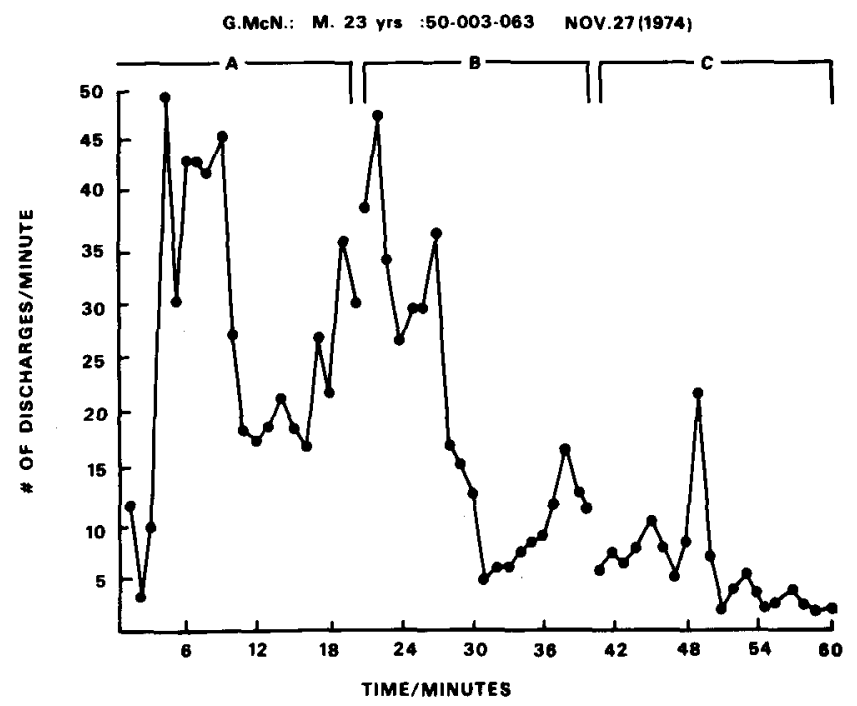

Figure 7-Trend analysis results on G. McN. M. 23. Nov. 27, 1974. (No. 50-003-063). The number of spike discharges per minute are displayed for 3 consecutive 20 minute epochs. A. Before feedback. B. During feedback of triggered auditory stimuli. C. After feedback. Note the reduction in the number of discharges during and after feedback. current activity if it was dangerous or, to rest. The window unit (see below) could be set for a minimum number of focal spikes in unit time, the number being determined during the monitoring phase when the unit was calibrated to the patient.

$b$. Via the window unit, to trigger somatosensory and auditory stimuli, so as to inhibit the spread of electrical activity in the cortex. These stimuli could be applied to the opposite ear or limbs, either separately or together.

$c$. To make the patient aware of any aura in association with the "electrical aura."

$d$. To teach the patient any manoeuvres (e.g. first clenching of concentration) which might inhibit the progression of seizure discharges after a warning of focal EEG activity.

$e$. To try to create "internalised inhibition" from the focal activity without the need for either an auditory or somatosensory stimulus. Inbibitory mechanisms may be important in the development of unilateral myoclonus amyotonus (Faidherbe et al, 1962).

We have found unilateral inhibition from continuous motor tasks in association with apparently generalized spike and slow wave activity. If it is accepted that some areas of cortex, when stimulated, suppress discharges in their immediate vicinity and decrease electrical activity from large cortical areas of both hemispheres (Penfield and Jasper, 1954), then feedback stimulation of some areas of cortex might inhibit focal discharges in adjacent areas.

$f$. To reduce anticonvulsant medications.

g. To control intractable epileptics in preference to treatment by destructive surgery which could always be performed at a later date.

$h$. To provide a simple monitoring system for known epileptics so they may know if they are achieving or losing control of the focal activity, and of their clinical attacks.

$i$. To try to reduce the development of secondary or mirror foci after known trauma or a known focus (Nie et al, 1973), as anticonvulsant medication may be ineffective (Rapport and Penry, 1973) in this respect.

As with the evaluation of any new technique it was necessary to choose subjects who had not been fully controlled by a prolonged trial of con- ventional treatment. In addition, we chose patients with clear focal discharges. We attempted to quantify the effects on the focal discharges which were used to trigger the stimuli.

\section{METHODS}

The thirteen patients selected for these trials had failed to gain complete control of their seizures after prolonged use of conventional medication in therapeutic quantities as assessed by serum levels. All the patients were told this new technique might not help. The EEG recordings of all the patients demonstrated clear focal and lateralized discharges of a relatively constant configuration.

Surface silver chloride electrodes were applied according to the International 10-20 system with electrode resistance maintained below $3 \mathrm{k} \Omega$. Sixteen channel recordings were made on Grass Model 8 EEG machines. A six channel Bell and Howell VR 3200 tape recorder was multiplexed in our laboratories to record 16 channels of EEG on quarter inch tape at $17 / 8$ ips.

Triggering from the focal EEG discharges was achieved by using Schmidt trigger units of our own design (Fig. 1)). The tone of the auditory stimulus varied with the voltage of the spike in order to minimize 
G.McN.: M. 23 yrs. 50-003-063

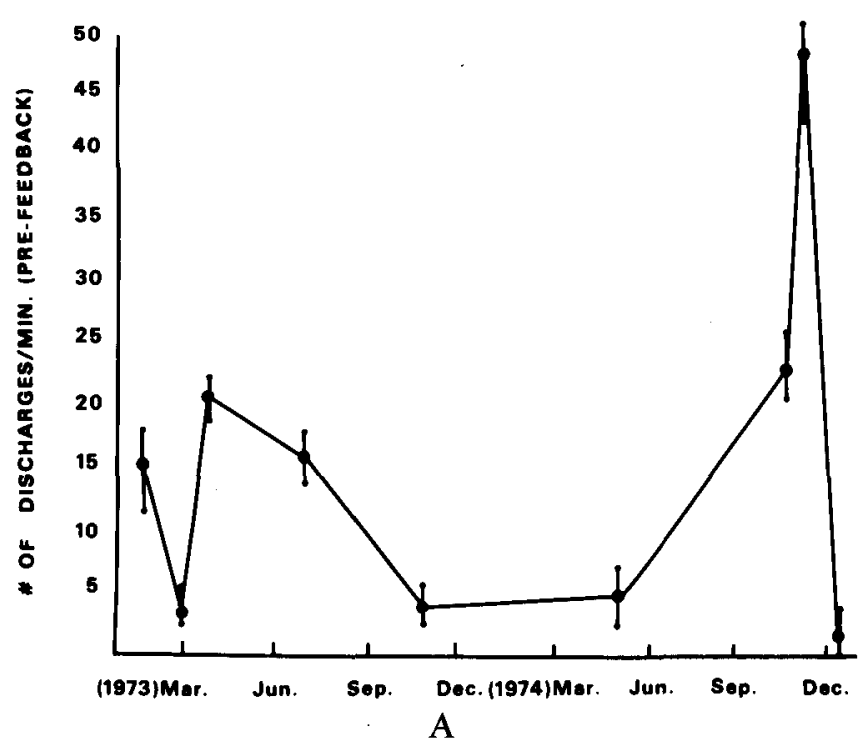

J.G.: F.22 yrs 5109-01-122-01
R.M.: M. 39 yrs: 3409-017

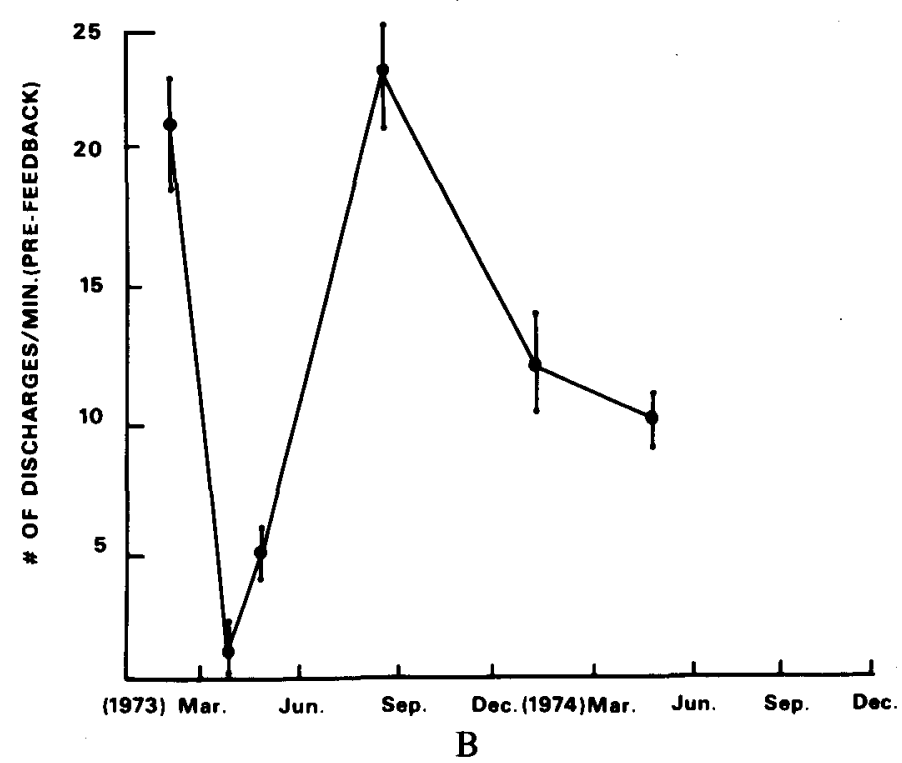

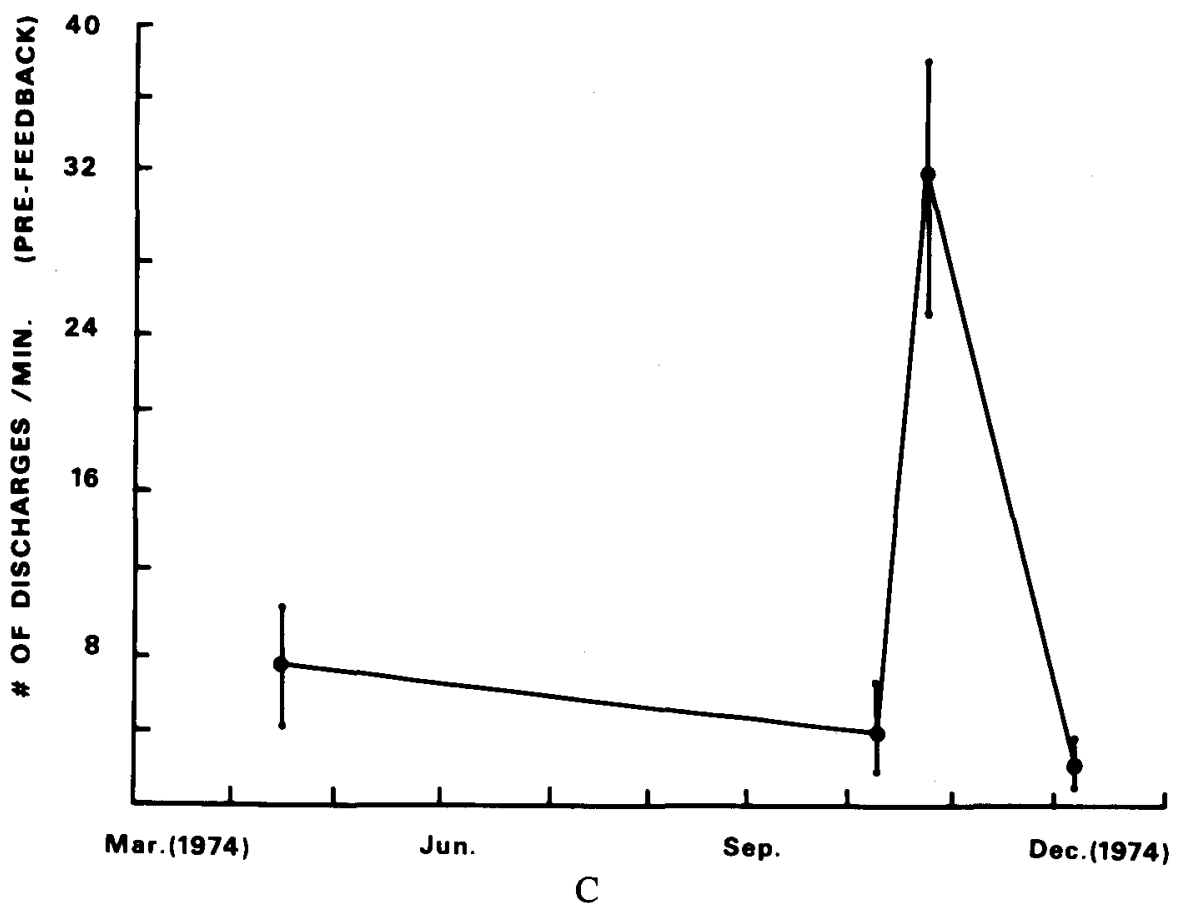

habituation (Fig. 2A, 2B), although this technique allowed information about the quality of the spike to be available to the patient.

Epochs of 20 to 30 minutes were chosen for control, feedback and post-feedback assessment. Control periods without stimulation and with random stimulation were compared with feedback and post-feedback sessions.
The number of spike discharges in unit time was assessed by trend analysis using a Hewlett-Packard 5480B Memory/Display, 5486A control and 5485A two channel input, the results being displayed on a $9862 \mathrm{~A}$ plotter using the $9810 \mathrm{~A}$ calculator (Fig. 3).

Some patients were videomonitored using a Sony S.E.G. 1 split-screen facility to record the pa-
Figure 8-The number of focal EEG discharges during separate visits to the unit are displayed as the Mean \pm SD of the discharges during the prefeedback 20 minute epoch. The results on three patients are presented.

A;-G. McN.: M. 23 yrs. 50-003-063

B;-R. M.: M. 39 yrs. 2409-17

C;-J. G.: F. 22 yrs. 5109-01-122-01.

Note the lack of any consistent reduction in the number of EEG discharges during consecutive visits. Compare these results with those in Figures 6 , 7, 9 and 11. 
R.M.: M.40 yrs. 3409-01.07 TLE Major/Minor Ep. L. TEMP. FOCUS

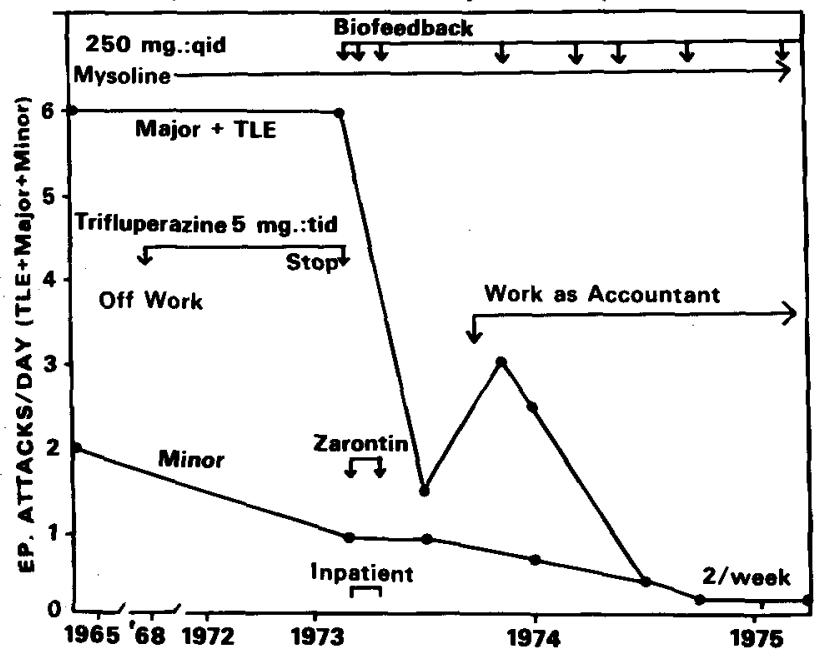

A.

Figure 9-The numbers of clinical fits reported by two patients during a long period are shown in association with other variables.

A) R.M. M 40. 3409-01-07. Temporal lobe and major seizures are displayed separately from the number of minor seizures. The patient kept a diary throughout the 10 year period. Seizures began at the age of 14 (1949) probably as a result of a head injury. There was a left mid-temporal lobe focus. There was a one centimeter calcified lesion in the left medial temporal lobe. Surgical treatment was thought to be unwise. He claimed to be able to reduce the number of seizures by "concentrating" when he felt abdominal discomfort, a "generalized feeling of numbness" or "strangeness" of his surroundings. Awareness of these phenomena seems to have

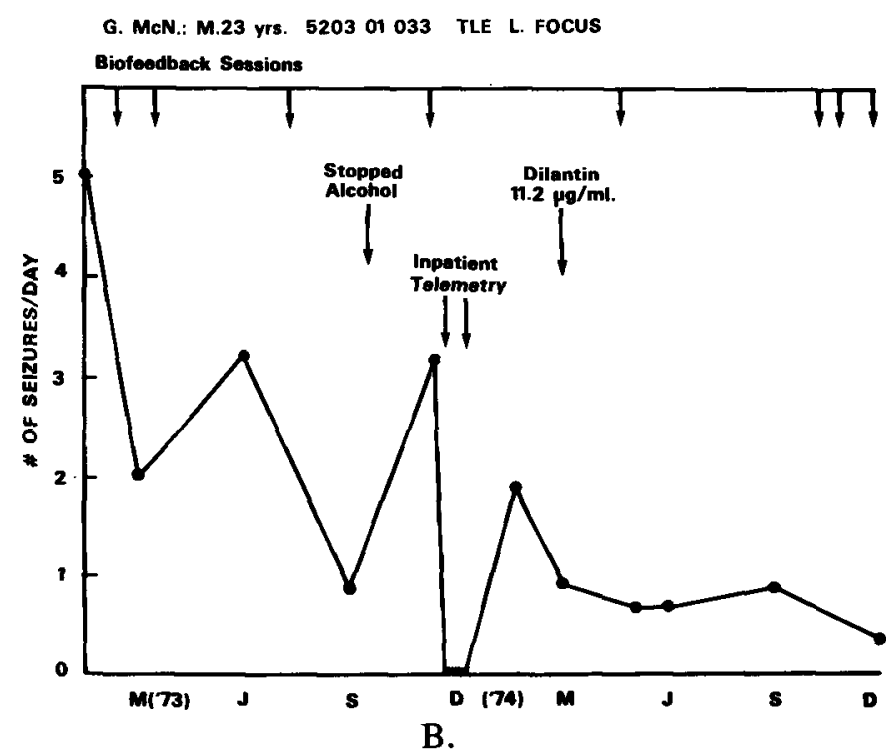

increased after auditory feedback sessions. Note the return to work (as an accountant) and cessation of Trifluperazine therapy since both may have influenced the number of clinical seizures.

B) G. McN. M 23. 5203-01-003. This patient developed seizures in 1965 and had a left anterior temporal lobe focus. The seizures involving staring, incontinence, unresponsiveness, rigidity, loss of muscle tone, and unconsciousness. Sometimes his gait became very slow and he might experience weakness in both legs before any impairment of consciousness. Note the cessation of alcohol intake in September, 1973. Only one serum level of Dilantin is indicated although the patient had been on the same dosage of the drug for more than three years. cutoff of $18 \mathrm{db}$ per octave were half wave rectified and integrated over a 10 second epoch. The stored and integrated signals were serialized via linear gates to generate voltage/frequency polygons for each of the 8 channels being analyzed together with an average polygon for each hemisphere. The results were stored on punched tape (Digitek) which was read by a HewlettPackard 9863A tape recorder into the Hewlett-Packard 9810A calculator and 9862A plotter (Fig. 4A and $4 \mathrm{~B}$ ).

During the preliminary assessment of a patient, the effects of various types of stimuli (e.g. auditory, somatosensory or photic) were assessed alone or in combination with various manoeuvres selected by the patient. Combinations of auditory and somatosensory stimuli were tried particularly if both produced some reduction in the number of spikes. Stimuli were presented ran- domly or they were triggered by the focal EEG disturbance. The patients were asked to increase or decrease the number of discharges with and without feedback stimuli. Movements such as fist clenching of the the limbs contralateral to the focus were always tried. Subsequent sessions involved the use of the stimulus which had been found most effective during the initial assessment and stimuli causing an increase in spike frequency were avoided.

Sessions were conducted in the same room and the conditions were standardized as far as possible, particular care being taken to reduce extraneous stimuli.

The numbers of focal EEG discharges during consecutive feedback sessions were assessed by the results of the trend analysis during the control (prefeedback) periods at the start of each session. The results were presented as the mean \pm standard deviation of the number of spikes over the twenty minute epoch after the spikes were counted per minute. Intervals between sessions varied from one day to six months over a three year period.

The number of clinical seizures was assessed from accounts by the patient and his relatives. Adequacy and constancy of medication was estimated by serum levels of prescribed anticonvulsants, the dosage being kept constant throughout the trial period.

Many factors could not be controlled such as the effect of the return to work on Patient 2. The reports of the number of clinical seizures may not be reliable and such information is not as objective as the trend analysis of the number of EEG complexes.

\section{RESULTS}

Thirteen patients aged two to 39 years (mean 15.1 years) were studied during the three year period from February 1972 and February, 1975 
(Fig. 5). A total of 46 feedback sessions were conducted, the number per patient varying from one to eleven (mean 3.5 sessions). There was a reduction in the number of focal EEG discharges during the feedback sessions in eight patients $(62 \%)$ with a dramatic reduction $(>50 \%)$ in the number of discharges in four (31\%) (Fig. 5). Some patients showed no significant residual effect in the epoch immediately following feedback (Fig 6) whereas other patients showed much less focal activity during this period (Fig. 7). Long term assessment of the number of focal discharges during the control periods showed no consistent reduction in the amount of focal activity (Fig. 8A, 8B, 8C) even though there was a progressive reduction in the number of clinical disturbances (Figs. 9A, 9B).

In one patient (JG) there was an increase in the frequency of focal discharges during auditory biofeedback (Fig. 10) when the sound stimulus was triggered by the spike. Randomly presented auditory stimuli of the same frequency and intensity produced a much smaller increase in spike frequency. Somatosensory impulses such as shock to the right hand produced a significant reduction in the number of spike discharges (Figs. 11A, 11B).

Four of the patients noticed that they experienced an aura in association with bursts of spike activity. One patient $(3$; C.S.) became aware of a peripheral sensory aura during the first biofeedback session (Fig. 12) and has remained free of minor seizures for 18 months.

In two patients $(1,2)$ there was greatest improvement in major and temporal lobe seizures with relatively less effects on minor disturbances although one patient (3) showed a complete resolution of minor seizures after one feedback session.

In some patients (e.g. 10) no immediate or long term effect on spike frequency was noted in response to a wide range of random or triggered stimulation. Other patients $(5,8)$ were not sufficiently cooperative to allow long term assessment and this may turn out to be one major limita-

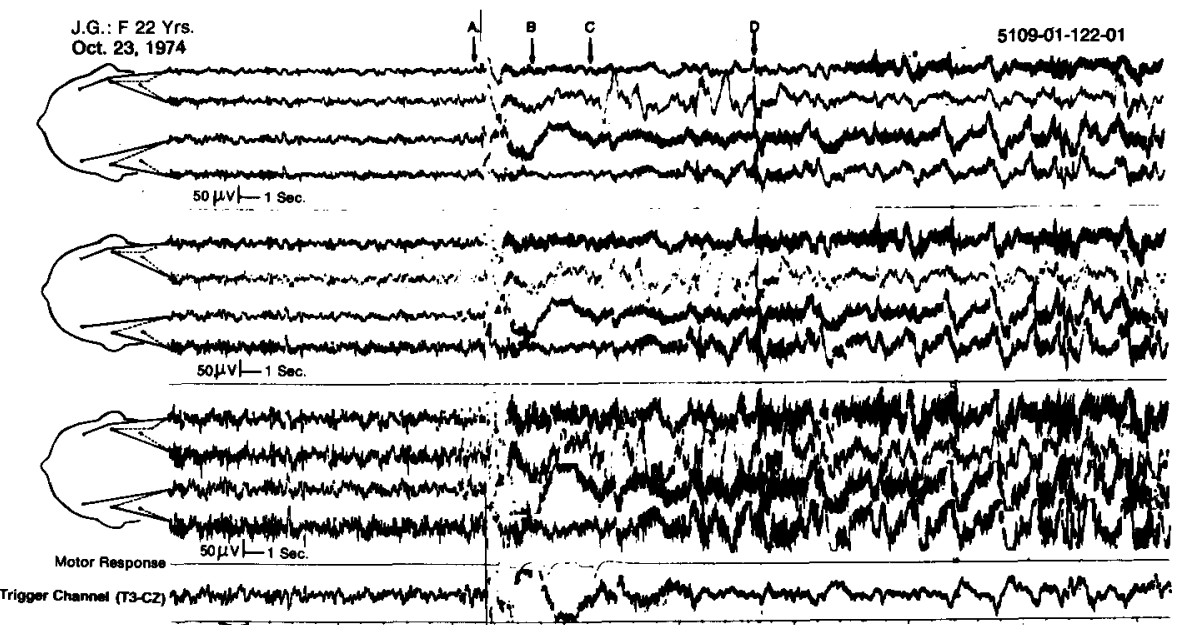

Figure 10-J.G. F 22 years. 5109-01-122-01. EEG tracing during auditory feedback of focal spike discharges. A) Auditory feedback with motor response. B) Perseveration of motor performance with perseveration of switch pressing in the right hand. C) She raised the right hand and waved. D) She cried "No, No, No!' She claims she could hear questions but could not reply. Subsequently the EEG recording showed a diffuse excess of slow waves for two minutes. Note aggravation of spike discharges and clinical seizure. During the seizure she raised the right arm and was unable to speak or understand verbal instructions. She had had grand mal seizures since the age of 18 and also experienced attacks in which she was unable to speak for 10 seconds to 10 minutes. She suffered from four to ten attacks per day of the latter. She had not had a grand mal seizure or deja vu attack for more than a year. At the time of the recording she was on $100 \mathrm{mg}$ of diphenylhydantoin b.i.d, primidone, 125 $\mathrm{mg}$ b.i.d. and phenobarbitone, $60 \mathrm{mg}$ t.i.d. Left anterior temporal sharp and slow wave focal discharges were seen in the EEG.

tion of any intermittent feedback technique.

The results of our initial studies do not allow us to state the optimum interval between feedback sessions but it is hoped that this information will be obtainable when we use our own continuous feedback unit.

\section{DISCUSSION}

Miller (1969) suggested that epileptic seizures might be prevented by conditioning subjects to refrain from producing the brain wave patterns that always precede a seizure. The basic principle of conditioning is to present a reward immediately after a response in order to increase the probability of that response. Although we are not providing an overt reward to the patient we hesitate to interpret out findings as indicating "voluntary" control of focal epileptic activity although the results of such experiments are often described in terms of "feedback control" or "biơfeedback". When the only apparent reinforcer is feedback, and some modification of the response occurs, it would be naive to assume that this indicates "voluntary" control because many other subtle reinforcers might be involved. Human subjects are usually motivated to cooperate with the requirements of an experiment (Orne, 1962) and feedback may indicate successful performance. There are many social and economic advantages for an epileptic to become free of seizures and the subjects of our experiments recognized that control of their EEG discharges might help them to achieve a reduction in seizure frequency.

In many subjects some types of feedback were more effective than others in suppressing focal EEG activity (Fig. 5). In one subject (J.G.) however, there was an increase in focal activity with random and triggered auditory stimuli, (suggesting that she suffered from a type of "reflex" epilepsy). In this patient there was a reduction in the frequency of focal temporal lobe activity during electric shock stimulation of a contralateral limb. Results such as these lead us to consider more basic mechanisms of neuronal activ- 


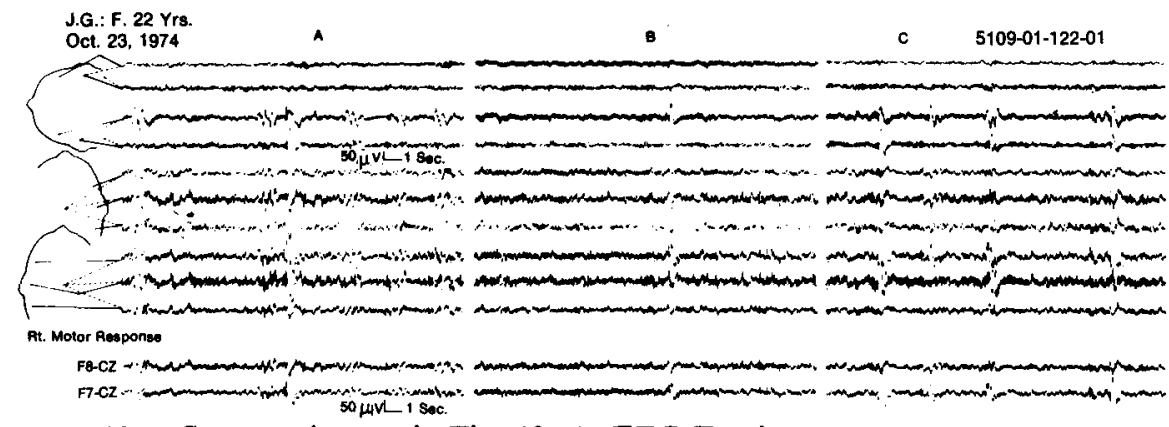

Figure $11 \mathrm{~A}-$ Same patient as in Fig. 10. A. EEG Tracing.

Figure 11B-Below. Trend analysis of number of spike discharges per minute. A. Before feedback. B. During triggered electric shock feedback to the contralateral upper limb. C. After feedback. Note the difference in the recordings during auditory feedback (Fig. 10) and during stimulation over the right median nerve.

\section{J.G. F. 22 yrs OCT. 231974 5109.01.122.01}

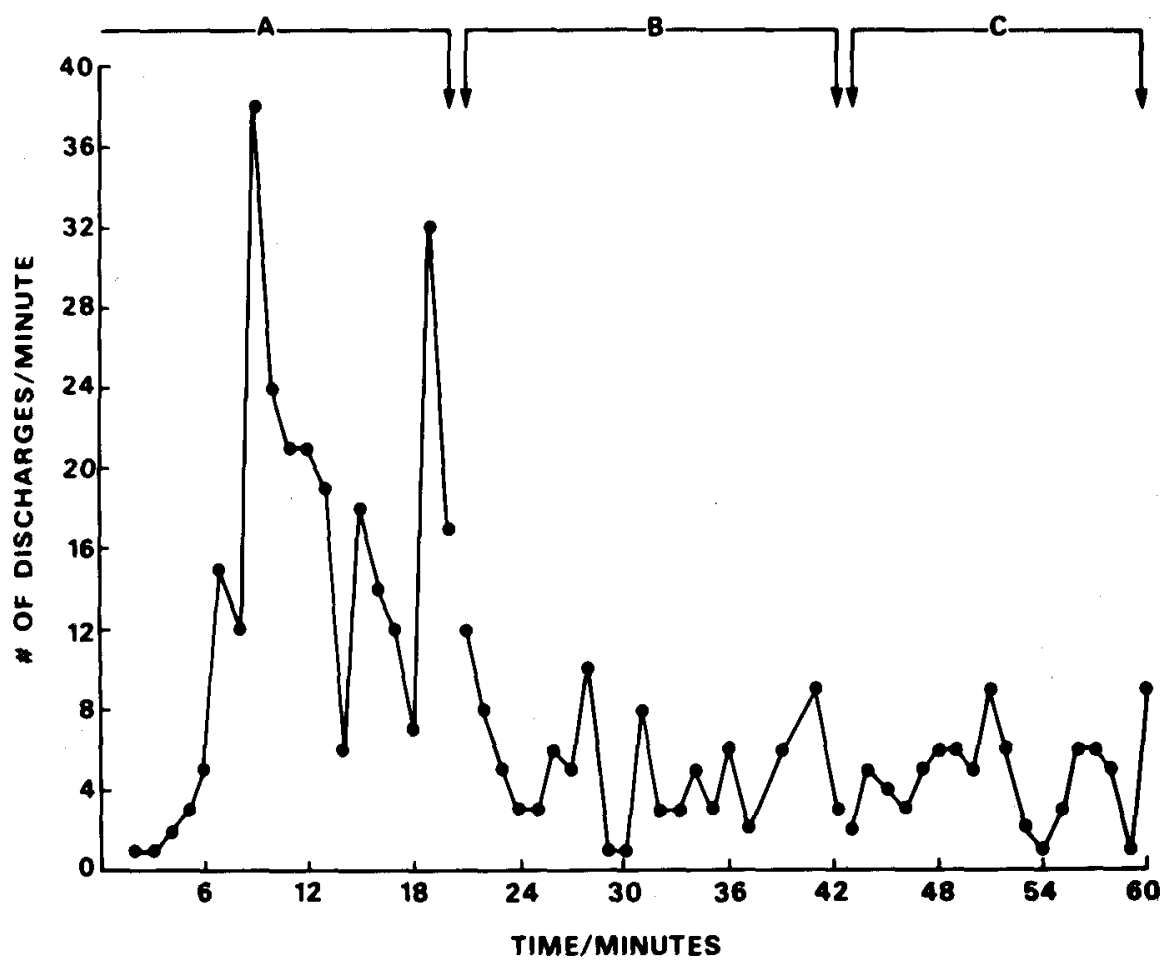

ity. In animals, experimentallyinduced focal epileptic discharges in exposed mammalian cortex may be associated with massive depolarization of the cell soma (paroxysmal depolarization shifts or PDSs). These PDSs are thought to be synaptically mediated since they can also be evoked by cortical or thalamic stimulation (Ajmone-Marsan, 1969). Many workers have shown that although the firing pattern of epileptic neurons may be abnormal interictally, the membrane properties of such neurons appear to be normal between PDSs. Most paroxysmal bursts are thought to be due to ab- normalities of synaptic bombardment and modification of this bombardment might be expected to modify the onset and spread of epileptic discharges. Sharpless and Halpern (1967) used implanted electrodes over chronically isolated cortex. They demonstrated that the capacity of the isolated region to sustain long epileptiform afterdischarges declined almost to normal following experimental sessions during which cited at 15 second intervals. The return of increased susceptibility to epileptiform discharges might require several days. Using a similar afterdischarges were repeatedly eli- technique, Rutledge, Ranck and Duncan (1967) found they could prevent increased susceptibility to epileptiform activity by daily stimulation involving 20 applications of a two second pulse train. It is possible that synaptic bombardment resulting from peripherally applied stimuli might modify activity of "epileptic" neurons in a focus. In the human the greatest problem in studying the effects of peripheral stimulation on focal activity is that the "focal" disturbance may be arising at a distance from the site of maximal electrical activity recorded by surface electrodes (David et al, 1970). The same problem would be encountered with depth electrodes or microelectrode sampling since many of the "foci" may arise from diffuse cortical and subcortical pathology. It is well known that spike discharges in children may "migrate" in serially performed EEG recordings (Trojaborg, 1966). Similar problems caused Meyers (1954) to question the validity of the whole concept of an epileptogenic focus. Although the neuronal mechanisms underlying the focal discharge are uncertain, it is still valid to study this type of discharge as an index of epileptic activity and furthermore the results can be readily quantitated. Spike and wave activity was not chosen for our early studies because such bursts are often associated with impairment of consciousness, as judged by the performance of bilateral and laternating motor task. This would have been a disadvantage in our study since we wished to obtain information about the subjective experiences of the patients during feedback sessions. For example, we wanted to know if the subjects experienced any aura; we also required an account of any manoeuvres they used to increase or decrease the number of discharges as this might lead to a better understanding of the "subtle reinforcers" in association with the feedback stimuli.

It was thought that feedback techniques would have their greatest application in those patients who experienced some form of aura or immediate warning of a fit; these comprise about half of all epileptic 


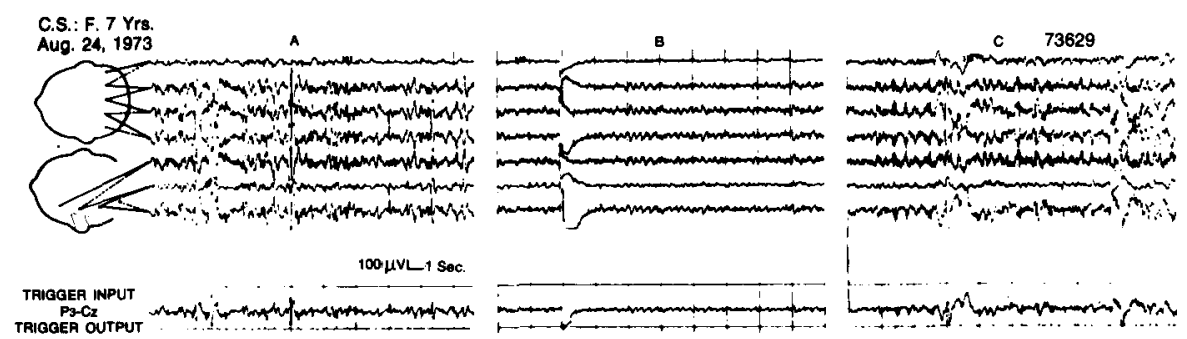

Figure 12-C.S.: F 7 years 6607-01-020-16. Bipolar EEG tracings. A. Before somatosensory (S.S.) feedback. B. During feedback with electric shocks to right arm. C. After feedback. She was hyperactive and had been retarded in speech development. Minor (and possibly some major seizures) had been noted prior to the feedback sessions in August, 1973. An EEG had shown sharp and slow wave complexes over the left posterior quadrant with maximal amplitude over the left parietal (P3) electrode. Subsequent to the feedback session there were no recorded minor seizures and she showed improvement in speech and intellectual performance. No major seizures were seen.

patients (56.2\% Lennox and Cobb, 1933). These auras may be of cortical localizing value and they are more common in patients with a history of brain injury $(70 \%)$ where focal features are more likely. Premonitory symptoms may occur for several days before a seizure (Henner, 1962) but the aura is usually regarded as part of the seizure (Gastaut, 1950; Penfield and Jasper, 1954). Abortive auras such as night terrors, dreamy states and myoclonic jerking may persist after major seizures have been controlled by anticonvulsant therapy (MonradKrohn, 1931). Unfortunately, some "auras" such as déjà vu attacks may occur in up to a third of the normal population (Henner, 1962). Since four $(31 \%)$ of our patients became aware only after feedback of their focal EEG activity it is possible that these techniques might benefit many patients by making them aware of some sensation in association with their paroxysmal EEG disturbances. Some patients may not realize that they experience an aura because of the amnesia resulting from a grand mal fit, for example, and the feedback procedure then allows them to appreciate the aura in the absence of a seizure. Once an aura has been recognized, the patient can then attempt to inhibit further seizure activity by such manoeuvres as fist clenching, or mental concentration (Paulson, 1963). In the feedback approach one is trying to modify the focal activity or its spread as a means of controlling the clinical seizures and therefore the feedback technique may be useful even when the patient is on enough medication to control most of the clinical seizures. Reduction of focal discharges may require many times the dose of medication required to control clinical seizures and our results reveal a similar association between fit frequency and number of focal discharges.

The preliminary results on 13 patients provide evidence that intermittent feedback sessions may allow an immediate reduction in the frequency of focal EEG discharges in about half the subjects but we have no evidence of any prolonged effect on the discharges even though seizure frequency was reduced in five out of 13 patients. Some patients (4) became aware of an "aura" and this allowed various inhibitory manoeuvres (e.g. concentration or fist clenching) to be employed. Interpretation of the preliminary results in terms of statistics is complicated by the fact that most of the patients chosen had had prolonged trials of conventional therapy and it would seem reasonable to expect better results in a larger study of more average patients.

The preliminary results have indicated an important limitation of the technique since one patient developed a fit during auditory feedback whereas there was a marked improvement in the same patient during somatosensory stimulation. It is clear that careful clinical and neurophysiological assessment is required before any feedback unit is used on epileptic patients.

Although the mechanisms of the reduction in spike and seizure frequency following intermittent feedback sessions is not clear it would seem that the technique may be helpful as a supplement to conventional therapy. We are hopeful that use of miniaturized and portable feedback units combined with telemetry and split screen videomonitoring will allow more detailed assessment of the clinical applications of the technique.

\section{ACKNOWLEDGEMENTS}

We are grateful to $\mathrm{Mr}$. T. Blogg and Douglas Teeple, who provided valuable technical assistance in the design and development of the EEG frequency analysis; Mr. Glen Shine, who designed and built the trigger and oscillator units and Miss Linda Glazier who provided secretarial services.

Professor Alan J. McComas gave invaluable advice and criticism throughout the project.

\section{REFERENCES}

ADRIAN, E. D. and MATTHEWS, B. H. C. (1934). The Berger Rhythm: potential changes from the occipital lobes in man. Brain. 57. 355-385.

AJMONE - MARSON, C. (1969). Acure effects of topical epileptogenic agents. In Basic Mechanisms of the Epilepsies. Ed. H. H. Jasper, A. A. Ward, Jr., and A. Page. London: Churchill, pp. 299-319.

ARDUINI, A. and LAIRY-BOUNES, G. C. (1952). Action de la stimulation électrique de la formation reticularie du bulbe et des stimulations sensorielles sue les ondes strychniques corticales chez les chat "encéphale isolé." Electroencephalography and Clinical Neurophysiology. 4: 503-512.

AURELIANUS, Caelius. (1755). De morbis chronics. Ed. J. C. Amman. Amsterdam.

BAIR, J. H. (1901). Development of voluntary control. Psychological Review (Washington). 8: 474-510.

BATES, J. A. V. (1962). The surgery of epilepsy in Modern Trends in Neurology. Vol. 3 (ed. Williams, D.). Butterworth, London.

BENNETT, D. R. Sleep derivation and major motor convulsions. Neurology. 13. 1963. 953-958.

BENNETT, D. R. (1964). Sleep derivation: Neurological and electroencephalographic effects. Aerospace Medicine (St. Paul 888-890. 
BEST, W. R. (1963). Drug associated blood dyscrasias. Journal of the American Medical Association. 185: 286-290.

BOOKER, H. E., FORSTER, F. M. and KLOVE, H. (1965). Extinction factors in startle (acoustimotor) seizures. Neurology (Minneap.) 15: 1095-1103.

BURES, J. (1953). External inhibition of the reflex epilepsy in rats and mice. Physiologia Bohemoslovenica. 2: 29 .

BURES, J. (1956). Reflex changes of paroxysmal activity in experiment and clinic. Casopis Lekaru Ceskych (Praha). 95: 393.

CHOCHOLOVA, L. (1962). Epileptic attacks and adaptation. Epilepsia. 3: 350-358.

COOKE, P. M. and SNIDER, R. S. (1955). Some cerebellar influences on electrically induced cerebral seizures. Epilepsia. 4: 19-28.

COOPER, I. S., AMIN, I., GILMAN, S. (1973). The effect of chronic cerebellar stimulation upon epilepsy in man. Transactions of the American Neurological Association. 98: 192-194.

CRADDOCK, W. L. (1955), Use of phenacemide in epilepsy with analysis of fatal reactions and case report. Journal of the American Medical Association. 159: 1437-1441.

CLRRIE, S., HEATHFIELD, K. W. G., HENSON, R. A., and SCOTT, D. F. (1971). Clinical course and prognosis of temporal lobe epilepsy. Brain. Vol. 94: P.I., pp. 173-190.

DAVID, M., TALAIRACH, J. and BANCAUD, J. (1970). Post-Traumatic epilepsies of multiple cortical origin. Epilepsia. II. 49-58.

DOW, R. S. (1965). Extrinsic regulatory mechanisms of seizure activity. Epilepsia. (Amst.) 6: 122-140.

DOW, R. S., FERNANDEZ-GUARDIOLA, A. and MANNI, E. (1962). The influence of the cerebellum on experimental epilepsy. Electroencephalography and Clinical Neurophysiology. 14: 383-398.

DURUP, G. and FESSARD, A. (1935). L'électroencéphalogramme de l'homme. Année Psychologique. 36: 1-35.

EFRON, R. (1956). The effect of olfactory stimuli in arresting uncinate fits. Brain. 79: 267-281.

EFRON, R. (1957). The conditioned inhibition of uncinate fits. Brain. 80: 251-262.

FABISCH, W. and DARBYSHIRE, R. (1965). Report on an unusual case of selfinduced epilepsy with comments on some psychological and therapeutic aspects. Epilepsia. 6: 335-340.

FAIDHERBE, J., FRANCK, G., GASTAUT, H. and REGIS, H. (1962). The characteristics of hemiconvulsive seizures in children. Electroencephalography and Clinical Neurophysiology. 14: $775 \mathrm{p}$.

FALCONER, M. A. (1953). Discussion of the surgery of temporal lobe epilepsy: the clinical study and selection of patients. Proceedings of the Royal Society of Medicine. 46: 971-974.
FALCONER, M. A. and KENNEDY, W. A. (1961). Epilepsy due to small foci temporal lesions with bilateral independent spikedischarging foci: a study of seven cases relieved by operation. Journal of Neurology, Neurosurgery and Psychiatry. 24: 205-212.

FALCONER, M. A., and CORSELLIS, J. A. N. (1964). Etiology and pathogenesis of temporal lobe epilepsy. Archives of Neurology (Chicago). 10: 233-248.

FALCONER, M. A. and TAYLOR, D. C. (1968). Surgical treatment of drug-resistant epilepsy due to mesial temporal sclerosis. Archives of Neurology (Chicago). 19: 353-361.

FERNANDEZ-GUARDIOLA, A., ALCARAZ, V. M. and GUZMAN, F. C. (1961). Inhibition of convulsive activity in the reticular formation. Acta Neurologica Latino Americana (Montevideo). 7: 30-36.

FERNANDEZ-GUARDIOLA, A., ALCARAZ, V. M. and GUZMAN, F. C. (1956). Motification de la descarga convulsive cortical por estimulation mesencefalica. Boletin de Estudios Medicos y Biologicos (Mexico). 14: 14-21.

FERNANDEZ-GUARDIOLA, A., OKUJAVA, V. M. and GUMA, E. (1968). Peripheral and central phenomena of postepileptic extinction. Epilepsia (Amsterdam). 9: 303-310.

FINKEL, K. C. and ISRAELS, S. (1959). Paradione nephrosis. Lancet. 79: 243.

FORSTER, F. M. and CAMPOS, G. B. (1964). Conditioning factors in stroboscopic induced seizures. Epilepsia. 5: 156-165.

FORSTER, F. M., HANSOTIA, P., CLEELAND, C. S. and LUDWIG, A. (1969). A case of voice-induced epilepsy treated by conditioning. Neurology (Minneapolis). 19: 325-331.

FORSTER, F. M., BOOKER, H. E. and GASCON, G. (1967). Conditioning therapy in musicogenic epilepsy. Transactions of the American Neurological Association. 92: 236.

FORSTER, F. M., KLOVE, H. M., PETERSON, W. G. and BENGZON, A. R. A. (1965). Modification of musicogenic epilepsy by extinction technique. Eighth International Congress of Neurology. 41: 269.

FORSTER, F. M. and LISKE, E. (1963). Role of environmental clues in temporal lobe epilepsy. Neurology (Minneapolis) 13: 301-305.

GASTAUT, H., REGIS, H., DONGIER, S. and ROGER, A. (1956). Conditionnement électroencéphalographique des décharges épileptique et notion d'épilepsie réflexo-conditionée. Revue Neurologique. 94: 829-835.

GASTAUT, H. and TASSINARI, C. A. (1966). Triggering mechanisms in epilepsy. Epilepsia. 7: 85-138.

GASTAUT, H. (1963). Epilepsies. Encephale-Encyclopedie MedicoChirurgical.

GASTAUT, H. (1950). Combined photic and metrazol activation of the brain. Elec- troencephalography and Clinical Neurophysiology. 2: 249.

GASTAUT, $H$. and FISCHER-WILLIAMS, M. (1959). The physiopathology of epileptic seizures. In J. Field (Ed.) Handbook of Physiology: A Critical Comprehensive Presentation of Physiological Knowledge and Concepts. Sec. 1., Vol. 1 (Neurophysiology). Williams and Wilkins, Baltimore, Md. 329-363.

GASTAUT, H., NAQUET, $R$, and FISCHER-WILLIAMS, M. (1958). The pathophysiology of grand mal seizures generalized from the start. Journal of Nervous and Mental Disease. 127: 21-23.

GORBACEVICH, A. B. O'nekotorykhystovnoreflektornykh mekhanizemakh epileptoidnogo propadka (Some conditioned reflex mechanisms of an epileptic seizure). Zhurna Neurpatologii i Psikhiatrii imrai S. S. Korsakova (Moskva). 44: 1955. 326.

GOLDIE, L. and GREEN, J. M, (1959). A study of the psychological factors in a case of sensory reflex epilepsy. Brain: 82: 505-524.

GREEN, J. D. and SHIMAMOTO, T. (1953). Hippocampal seizures and their propagation. Archives of Neurology and Psychiatry. (Chicago). 70: 687-702.

GUERRERO-FIGUEROA, R., BARROS, A., HEATH, R. G. and GONZALES, G. (1964). Experimental subcortical epileptiform focus. Epilepsia (Amsterdam) 5: 112-139.

GUNDMUNDSSON, G. (1966). Epilepsy in Iceland. Acta Neurologica Scandinavica. 43: Suppl. 25: 124pp.

HENNER, K. (1962). Aurae and their role in reflex mechanisms of epileptic seizures. Epilepsia, 3; 391-401.

HOLUBAR, J. (1966). Penicillin and minor cortical foci in rats. In: Z. Zervit (Ed.) Comparative and Cellular Pathophysiology of Epilepsy. Excerpta Medica Foundation, New York. pp. 204-212.

HOWE, R. C. and STERMAN, M. B. (1973). Somatosensory system evoked potentials during waking behaviour and sleep in the cat. Electroencephalography and Clinical Neurophysiology. 34: 605-618.

HUGHES, J. R. (1966). Bilateral EEG abnormalities on corresponding areas. Epilepsia (Amsterdam). 7: 44-52.

HUGHES, J. R. (1967). EEG epileptiform abnormalities in different ages. Epilepsia (Amsterdam). 8: 93-104

JASPER, H. and SHAGASS, C. (1941). Conditioning occipital alpha rhythm in man. Journal of Experimental Psychology. 28: 373-388.

JUNG, R. (1949). Kirnelektrische Untersuchungen uber den Electrokrampf die Erregungsablaufe in corticalen Hirnregionen bei Katz und Hund., Archives of Psychiatry and Neurology. 183: 206-244.

KRUSE, R. (1968). Osteopathien bei antiepileptischer Langzeittherapie Mschr. Kinderheilk, 116: 378-381. 
KOPELOFF, L. M., BARERRA, S. E. and KUPELOFF, N. (1948). Temporal and spatial distribution of changes during spontaneous seizures in monkey brain. Journal of Neurophysiology. 11: 377-386.

KOPELOFF, L. M., CHUSID, J. G. and KOPELOFF, N. (1954). Chronic experimental epilepsy in Macaca mulatta. Neurology (Minneapolis) 4: 218-227.

KOREIN, J., MACCARIO, M., CARMONA, A., RANDT, C. T. and MILLER, N. (1971). Operant conditioning techniques in normal and abnormal EEG states. Proceedings of the Annual Meeting of the American Academy of Neurology. 29-30.

KRAFT, D., VON HERVATH, D., SCHAEFER, K. (1974). Retarded growth of rats by anticonvulsant drugs. Epilepsia. 15: 81-90.

KREINDLER, A. (1955). Epilepsia. Edit. Acad. Repibl. Popul. Romine. Bucarest.

KREINDLER, A. (1965). Experimental Epilepsy (Progress in Brain Research, Vol. 19). Elsevier, Amsterdam. 19: 160-167.

KREINDLER, A. (1962). Active arrest mechanisms of epileptic seizures. Epilepsia. 3: 329-337.

KULIGOWSKI, Z. W., BARANSKA, M., ZAREMBA, $M$. and ZEILINSKI, J. J. (1972). Follow-up observation and further treatment of epileptic patients at the psychoneurological Research Institute (In Polish). Neurologica i Neurochirurgia Polsa (Warszawa). 6: 2: 283-288.

KUTT, H. and PENRY, J. K. (1974). Usefulness of blood levels of antiepileptic drugs. Archives of Neurology. 31: 283-288.

LAGRUTTA, V., AMAIO, G. and ZAGUMI, M. T. (1971). The importance of the caudate nucleus in the control of convulsive activity in the amygdaloid complex in the temporal cortex of the cat. Electroencephalography and Clinical Neurophysiology. 31: 57-69.

LAIRY-BOUNES, G. C., PARMA, M. and ZANCHETTI, A. (1952). Modifications pendant la reaction "d'arret" de Berger de l'activite convulsive produite par l'application locale de strychnine sur le cortex cerebral de lapin. Electroencephalography and Clinical Neurophysiology. 4: 495-502.

LENNOX, W. G., and COBB, S. (1933). Eppilepsy: XIII. Aura in epilepsy; Statistical review of 1,359 cases. Archives of Neurology and Psychiatry. 30: 374-387.

LIDDELL, D. W. (1965). The uses of epilepsy. Journal of Psychosomatic Research. Res. 9: 21-23.

LIVINGSTON, S. (1956). Etiologic factors in adult convulsions. New England Journal of Medicine. 254: 1211-1216.

LOCKARD, J. S., WILSON, W. L. and UHLIR, V. (1972). Spontaneous seizure frequency and avoidance conditioning in monkeys. Epilepsia. 13: 437-444.

MAIER, N. R. F. and GLASER, N. M. (1947). Studies of abnormal behaviour in the rat. Part 10. Influence of age and sex on the susceptibility to seizures during auditory stimulation. Journal of Comparative Physiology and Psychiatry. 40: 73.

MARTINEK, Z. and HORAK, F. (1970). Development of so-called genuine epileptic seizures in dogs during emotional excitement. Physiologica Bohemoslovenica. 19: 185-195.

MEADOW, S. R. (1968). Anticonvulsant drugs and congenital abnormalities. Lancet 2: 1296.

MEADOW, S. R. (1970). Congenital abnormalities and anticonvulsant drugs. Proceedings of the Royal Society of Medicine. 63: 48-49.

MERRITT, H. H. (1947). "Historical Review of the pharmacologic approach to the treatment of epilepsy", in Hoch, P. H. and Knight, R. P. (eds.) Epilepsy: Psychiatric aspects of convulsive disorders. New York: Grune and Stratton, Inc.

MEYERS, R. (1954). The surgical treatment of focal epilepsy: an inquiry into current premises, their implementation and the criteria employed in reporting results. Epilepsia (Amsterdam). 3: 1-28.

MILLER, N. E. (1969). Learning of visceral and grandular responses. Science. 163: 434-445.

MONRAD-KROHN, G. H. (1931). The clinic of epilepsy. Acta Psychiatrica et Neurologica. 6: 137-157.

MULHOLLAND, T, and RUNNALS, S. (1962). Evaluation of attention and alertness with a stimulus-brain feedback loop. Electroencephalography and Clinical Neurophysiology. 14: 847-852.

MULLHOLLAND, T. B. (1968). Feedback electroencephalography. Activitas Nervosa Superior (Praha), 10: 410-438.

MUTANI, R., BERGAMINI, L. and GORIGUZZI, T. (1969). Experimental evidence for the existence of an extrarhinencephalic epileptogenic focus. Part 1 (Effects of the paleocerebellar stimulation). Epilepsia. (Amsterdam). 10: 351-362.

NAQUET, R. (1961). Conditionnement de discharges hypersynchrones epileptiques chez l'homme et l'animal. In: Brain Mechanisms and Learning. 625-639.

NIE, V., UPTON, A. and ETTLINGER, G. (1973). Behavioural impairment in the monkey following implantation of aluminum hydroxide on the temporal cortex: the role of cortical destruction. Experimental Neurology. 40: 632-651.

NOWLIS, D. P. and KAMIYA, J. (1970). The control of electroencephalographic alpha rhythms through auditory feedback and associated mental activity. Psychophysiology. 6: 476-484.

ORNE, M. T. (1962). On the social psychology of the psychological experiments with particular reference to demand characteristics and their implications. American Psychologist. 17: 776-783.

PAULSON, G. W. (1963). Inhibition of seizures. Diseases of the Nervous System. 24: 657-664.
PENFIELD, W. G. and ERICKSON, C. (1941). Epilepsy and cerebral localization. Springfield: Charles C. Thomas.

PENFIELD, W. G. and STEELMAN, $\cdot \mathbf{H}$. (1947). The treatment of focal epilepsy by cortical excision. Annals of Surgery. 126: 740-762.

PENFIELD, W. and JASPER, H. (1954). Epilepsy and the functional anatomy of the human brain. Little, Brown and Co. Boston. p. 654.

PETRAN, M. (1953). Contribution to Pathogenesis of Experimental Epilepsy with special reference to the balance and dynamics of excitation and inhibition. Thesis Prague.

PITHA, V. (1938). Epilepsie réflexe. Revue Neurologique. 70: 178-181.

PUDENZ, R. H., BULLARA, L. A., DRU, D. and TALALLA, A. (1975). Electrical stimulation of the brain. II. Effects on the blood-brain barrier. Surgical Neurology. In Press.

RAPPORT, R. L. and PENRY, J. K. (1973). A survey of attitudes toward the pharmacological prophylaxis of post-traumatic epilepsy. Journal of Neurosurgery. 38 : 159-166.

REIMER, G. R., GRIMM, R. J. and DOW, R. S. (1967). Effects of cerebellar stimulation on cobalt-induced epilepsy in the cat. Electroencephalography and Clinical Neurophysiology. 23: 456-462.

REYNOLDS, E. H. (1967). Effects of folic and on ise mental state and fit frequency of drug-treated epileptic patients. Lancet I. 1086-1088.

ROSENFELD, S., SWILLER, A. I., SHENOY, Y. M. Y. and MORRISON, A. N. (1961). Syndrome simulating lymphosarcoma induced by diphenylhydantoin sodium. Journal of the American Medical Association. 176: 491.

ROTH, S. R., STERMAN, M. B. and CLEMENTE, C. D. (1967). Comparison of EEG correlates of reinforcement. Internal inhibition and sleep. Electroencephalography and Clinical Neurophysiology. 23: 509-520.

RUTLEDGE, L., RANCK, J. and DUNCAN, J. (1967). Prevention of supersensitivity in partially isolated cerebral cortex. Electroencephalography and Clinical Neurophysiology. 23: 256.

SACKS, B., FENWICK, P. B. C., MARKS I., FENTON, G. W. and HEBDEN, A. (1972). An investigation of the autocontrol of the alpha rhythm and possible associated feeling states using visual feedback. Electroencephalography and Clinical Neurophysiology. 32: 461-463.

SHAGASS, C. (1942). Conditioning the human occipital alpha rhythm to a voluntary stimulus. A quantitative study. Journal of Experimental Psychology. 31: 367-379.

SHARPLESS, S. K. and HALPERN, L. (1967). The electrical excitability of chronically isolated cortex studied by means of permanently implanted electrodes. Elec- 
troencephalography and Neurophysiology. 23: pp. 256.

SMALL, J. G., STEVENS, J. R. and MULSTEIN, V. (1964). Electroclinical correlates of emotional activation of the electroencephalogram. Journal of Nervous and Mental disease. 1381. p. 146-155.

SNEDDON, I. B. and LEISHMAN, A. W. D. (1952). Severe and fatal phenobarbital eruptions. British Medical Journal. 1: 1276.

SNIDER, R. S. and COOKE, P. M. (1954). Cerebral seizures as influenced by cerebellar stimulation. Transactions of the American Neurological Association. 79: 87-89.

STERIADE, M. (1960). Mechanisms de facilitare si inhibitc in epilepsia penicilinica focal corticale. Studii si cercetari de neurologie. 5: 463-471.

STERMAN, M. B. (1973). Neurophysiological and clinical studies of sensorimotor EEG biofeedback training: Some effects on epilepsy. In: L. Birk (Ed.). Seminars in Psychiatry. Vol. 5: 507-525.

STERMAN, M. B. and FRIAR, L. (1972). Suppression of seizures in an epileptic following sensorimotor EEG feedback training. Electroencephalography and Clinical Neurophysiology. 33: 89-95.

STERMAN, M. B., LOPRESTI, R. W. and FAIRCHILD, M. D. (1969a). Electroencephalographic and Behavioural Studies of Monomethyl Hydrozine Toxicity in the Cat. Technical Report. AMRL-TR-69-3. Air Systems Command, Wright-Patterson Air Force Base, Ohio.
STERMAN, M. B., LUCAS, E. A. and MACDONALD, L. R. Periodicity within sleep and operant performance in the cat. Brain Research. 38: 1972. 327-341.

STERMAN, M. B., WYRWIĆKA, W. and ROTH, S. R. (1969). Electrophysiological correlates and neural substrates of alimentary behaviuur in the cat. In: J. P. Morgane and M. Wayner (Eds.) Neural Regulation of Food and Water Intake. Annals of the New York Academy of Science. 156: 723-739.

STERMAN, M. B., MACDONALD, L. R. and STONE, R. K. (1974). Biofeedback Training of the Sensorimotor electroencephalogram rhythm in Man: Effects on Epilepsy. Epilepsia. 15: 395-416.

STEVENS, J. R. (1961). Sensory stimulation in centrencephalic and focal cortical epilepsy. Electroencephalography and Clinical Neurophysiology. 13: 309.

SYMONDS, C. (1961). Some observations on facilitation or arrest of epileptic seizures. Chap 11. in Scientific Aspects of Neurology. H. Garland ed. London, E. S. Livingstone Ltd.

TROJABORG, W. (1966). Focal spike discharges in children. A Longitudinal study. Acta Paediatrica Scandinavica. 168: 113p.

UPTON, A. R. M. Biofeedback control of focal epilepsy. Federation of the Western Societies of Neurological Sciences. San Diego, California. February 28, 1975.

WADA, J. and CORNELIUS, L. R. (1960). Functional alteration of deep structures in cats with chronic focal cortical irritative le- sions. Archives of Neurology (Chicago). 3: 425-557.

WARD, Jr. A. A., McCULLOCH, W. S. and KOPELOFF, N. (1948). Temporal and spatial distribution of changes during spontaneous seizures in monkey brain. Journal of Neurophysiology. 11: 377-386.

WEINBERG, M. H. (1945). Fatigue as a precipitating factor in latent epilepsy. Journal of Nervous and Mental Disorders. 101: 251-256.

WELTON, D. G. (1950). Exfoliative dermatitis and hepatitis due to phenobarbital. Journal of the American Medical Association. 143: 232-234.

WHITTY, C. W. M., LISHMAN, W. A. and FITZGIBBON, J. P. (1964). Seizures induced by movement: a form of reflex epilepsy. Lancet 1: 1403-1406.

WILDER, B. J. and MORRELL, F. (1967). Secondary epileptogenesis in the frog forebrain. Neurology (Minneapolis). 17: 10411051.

WILDER, B. J. and MORELL, F. (1967). Cellular behaviour in secondary epileptic lesions. Neurology (Minneapolis). 17: 1193-1204.

WYRWICKA, W. and STERMAN, M. B. (1968). Instrumental conditioning of sensorimotor cortex EEG spindles in the waking cat. Physiology of Behaviour. 3: 703. 707 .

ZEILINSKI, J. J. (1974). Epileptics not in treatment. Epilepsia. 15: 203-210. 